\title{
Improved Student Learning Outcomeslln Learning Theme 4 Clean And Healthy Living At Home With Video Media And Power Points On Google Meet
}

\section{Wahab Prayitno}

SD Negeri Gringgingsari kangwahib81@gmail.com

\section{Article History}

accepted 14/11/2020

approved $21 / 11 / 2020$

published 26/11/2020

\begin{abstract}
The purpose of this study was to improve student learning outcomes on clean and healthy living materials at home in grade II elementary schools with the Project Based Learning (PjBL) learning model on google meet. The research conducted was a Classroom Action Research $(C A R)$ in two cycles, with each cycle consisting of one meeting. The stages of each cycle are planning, implementing, observing and reflecting. Each meeting is carried out with a knowledge assessment and attitude assessment to determine the development of students. In cycle I students who completed after carrying out the post test were 33\%. In cycle II participants students who completed after carrying out the post test were $89 \%$. These results indicate that the Project Based Learning (PjBL) learning model can improve the learning outcomes of students in theme 4 living clean and healthy in Class II homes at SDN 2 Gringgingsari.
\end{abstract}

Keywords: Learning outcomes, project based learning, theme 4

\section{Abstrak}

Tujuan dari penelitian ini adalah untuk meningkatkan hasil belajar peserta didik pada materi hidup bersih dan sehat di rumah di sekolah dasar kelas II dengan model pembelajaran Project Based Learning (PjBL) di google meet. Penelitian yang dilakukan adalah Penelitian Tindakan Kelas (PTK) sebanyak dua siklus, dengan setiap siklusnya terdiri dari satu pertemuan. Tahapan setiap siklusnya adalah perencanaan, pelaksanaan, observasi dan refleksi. Setiap pertemuan dilakukan penilaian pengetahuan dan penilaian sikap untuk mengetahui perkembangan peserta didik. Pada siklus I peserta didik yang tuntas setelah melaksanakan post test sebesar $33 \%$. Pada siklus II peserta didik yang tuntas setelah melaksanakan post test sebesar $89 \%$.. Hasil ini menunjukan bahwa model pembelajaran Project Based Learning (PjBL) dapat meningkatkan hasil belajar peserta didik tema 4 hidup bersih dan sehat di rumah Kelas II di SDN 2 Gringgingsari.

Kata kunci: Hasil belajar, project based learning, tema 4

\begin{tabular}{ll}
\hline Social, Humanities, and Education Studies (SHEs): Conference Series & \\
https://jurnal.uns.ac.id/shes & p-ISSN 2620-9284 \\
e-ISSN 2620-9292
\end{tabular}




\section{PENDAHULUAN}

Pendidikan merupakan bagian integral dalam pembangunan. Proses pendidikan tak dapat dipisahkan dari proses pembangunan itu sendiri. Pembangunan diarahkan dan bertujuan untuk mengembangkan sumber daya yang berkualitas. Manusia yang berkualitas dapat dilihat dari segi pendidikan. Hal ini terkandung dalam tujuan pendidikan nasional, bahwa pendidikan nasional bertujuan untuk mencerdaskan kehidupan bangsa dan mengembangkan manusia seutuhnya, selain beriman, bertakwa pada Tuhan Yang Maha Esa serta sehat jasmani dan rohani, juga memiliki kemampuan dan keterampilan. Dengan penegasan itu berarti peningkatan kualitas sumber daya manusia haruslah dilakukan dalam konteks peningkatan pengetahuan dan keterampilan melalui model pengajaran yang efektif dan efisien serta mengikuti perkembangan zaman.

Kemajuan di bidang ilmu pengetahuan dan teknologi memberikan dampak tertentu terhadap sistem pengajaran. Kepemilikan gadget/gawai dan teknologi lainnya seperti laptop dan komputer telah membuat peserta didik menjadi sosok yang adaptif terhadap perkembangan abad 21. Adanya berbagai platform pendidikan tentunya juga sangat bermanfaat untuk memberikan warna baru bagi pendidikan di Indonesia.

Sudah lebih dari setengah tahun lamanya, Indonesia didera pandemic covid19. Pandemi ini mengakibatkan pembelajaran tatap muka dihentikan di berbagai daerah. Efeknya, peserta didik pun hanya melakukan pembelajaran secara daring di rumah dengan bantuan orang tuanya. Efektif kah? Tentu ada yang efektif ada yang tidak. Semua dilihat dari individu peserta didik, guru dan peran orang tua masing-masing. Pendidikan di masa pandemic ini kurang menjadi perhatian guru dalam kaitannya dengan penggunaan media daring. Guru cenderung melakukan pembelajaran hanya melalui whatsapp grup. Materi dan penugasan-penugasan hanya dibagikan melalui whatsapp grup tanpa melihat ketercapaian peserta didik. Apabila ketercapaian pendidik terlihat, pengukurannya hanya sebatas pada pengumpulan tugas-tugas saja. Hal ini tentu saja sangat mempengaruhi hasil dari pembelajaran itu sendiri. Karena, sejatinya meskipun di masa pandemic seperti ini, peser didik tetaplah berhak untuk mendapatkan pendidikan dan proses pembelajaran dengan mengintegrasikan hasil di dalamnya. "Salah satu permasalahan yang terjadi di Pembelajaran Tematik kelas rendah adalah kepemahaman peserta didik akan materi pembelajaran yang disampaikan secara daring oleh guru."

Guru selain sebagai pengajar, juga berperan sebagai peneliti untuk perbaikan pembelajaran di kelasnya. Agaknya memang strategi/pendekatanpendekatan saja belum cukup untuk menghasilkan perubahan. Meier (2002 : 54) menyatakan bahwa belajar adalah berkreasi bukan mengkonsumsi. Pengetahuan bukanlah suatu yang diserap oleh pembelajaran, melainkan sesuatu yang diciptakan oleh pembelajar. Dalam upaya itu peserta didik perlu guru sebagai pengarah dan pembimbing. Di dalam pembelajaran daring, tugas guru adalah membantu peserta didik mencapai tujuan. Maksudnya guru lebih banyak berurusan dengan strategi dan alat bantu yang dikenal peserta didik daripada memberi informasi. Seperti yang terdapat pada peserta didik kelas II SD Negeri Gringgingsar

Menurut Sujana (2009: 3) hasil belajar peserta didik pada hakekatnya adalah perubahan tingkah laku. Tingkah laku sebagai hasil belajar dalam pengertian yang luas mencakup bidang kognitif, afektif dan psikomotoris. Selain perubahan tingkah laku, jika di sekolah hasil belajar biasanya dinilai dengan angka. Peserta didik akan mendapat nilai yang akan menggambarkan keberhasilan dalam belajar. Pembelajaran materi ini peneliti menggunakan model pembelajaran Project Based Learning ( $\mathrm{PjBL}$ ) merupakan salah satu model pembelajaran yang berpijak pada 
teori belajar konstruktivistik. Driscoll dalam Miyarso (2019: 120) menyatakan prinsip-prinsip pembelajaran kontruktivistik adalah melibatkan pebelajar dalam aktivitas nyata, negosiasi sosial dalam proses belajar, kolaboratif dan pengkajian multiperspektif, dukungan menentukan tujuan dan mengatur proses belajar, dan dorongan merefleksikan apa dan bagaimana sesuatu dipelajari. Menurut Surya, dkk (2018) Model pembelajaran Project Based Learning (PjBL) merupakan pembelajaran yang inovatif yang berpusat kepada peserta didik (Student Centered) dan menempatkan guru sebagai motivator dan fasilitator, dimana dalam hal ini peserta didik diberi peluang untuk bekerja secara otonom mengkonstruksi belajarnya. Model pembelajaran berbasis proyek (Project Based Learning) peserta didik merancang sebuah masalah dan mencari penyelesaiannya sendiri, sehingga mampu meningkatkan kreatifitas siswa untuk memunculkan penyelesaiannya sendiri membuat kegiatan pembelajaran lebih bermakna sehingga teringat.

Menurut Nurfitriyanti (2016) project based learning adalah pembelajaran yang memerlukan jangka waktu panjang, menitikberatkan pada aktifitas peserta didik untuk dapat memahami suatu konsep atau prinsip dengan melakukan investigasi secara mendalam tentang suatu masalah dan mencari solusi yang relevan serta diimplementasikan dalam pengerjaan proyek, sehingga peserta didik mengalami proses pembelajaran yang bermakna dengan membangun pengetahuannya sendiri.Penekanan pembelajaran terletak pada aktifitas peserta didik untuk memecahkan masalah dengan menerapkan keterampilan meneliti, menganalisis, membuat, sampai dengan mempresentasikan produk pembelajaran berdasarkan pengalaman nyata. Metode pembelajaran project based learning memperkenankan peserta didik untuk dapat bekerja mandiri maupun dengan cara berkelompok dalam menghasilkan hasil proyeknya yang bersumber dari masalah kehidupan sehari-hari. Langkah dalam model pembelajaran Project Based Learning sangat memerlukan kemampuan berpikir kreatif peserta didik. Suatu proyek yang ideal adalah merupakan sesuatu yang baru dan asli, namun hal ini tidaklah mutlak bagi peserta didik. Dapat pula peserta didik bekerja dalam suatu proyek yang bertolak dari ide orang lain, tetapi kemudian mengadakan modifikasi dari dasar pemikiran (Efrimal, dkk, 2017).

\section{METODE}

Penelitian ini adalah penelitian tindakan kelas (Classroom Action Research) dengan menerapkan model pembelajaran Project Based Learning (PjBL). Menurut Kurt Lewin dalam Kunandar (2011: 42) penelitian tindakan kelas ini terdiri dari empat tahapan dasar yaitu perencanaan (planning), pelaksanaan (acting), pengamatan (observing) dan refleksi (reflecting). Analisis penelitian ini adalah analisis deskriptif kuantitafif kualitatif dimana dalam penelitian ini selain penyajian hasil berupa data maupun angka peneliti juga menentukan bagaimana cara pengolahan hasil penelitian yakni dengan membuat analisisnya dengan menerapkan model penelitian Project Based Learning (PjBL). Penelitian ini dilaksanakan pada peserta didik kelas II SD Negeri Gringgingsari Tahun Pelajaran 2020/2021 selama dua siklus secara daring menggunakan aplikasi Google meet dengan dua pertemuan disetiap siklusnya. Siklus I dilaksanakan pada tanggal 16 - 21 November 2020. Siklus II dilaksanakan pada tanggal 23-26 November 2020 baik pre test maupun post test. Observasi meliputi observasi keterlaksanaan model pembelajaran $\mathrm{PjBL}$, sikap peserta didik dan keterampilan. Untuk hasil belajar menggunakan tes melalui Google form.

\section{HASIL DAN PEMBAHASAN}

Pada siklus I pembelajaran dilaksanakan selama satu pertemuan, setiap pertemuan diadakan penilaian pengetahuan dan penilaian sikap. Untuk mengetahui 
perkembangan peserta didik selama pembelajaran. Siklus I membahas materi tentang hidup bersih dan sehat, Pembelajaran dengan model PjBL dilaksanakan dengan 6 langkah PjBL secara berurutan mulai dari menentukan pertanyaan mendasar, merancang proyek, menyusun jadwal, memantau proses proyek, penilaian hasil dan evaluasi pengalaman. Proyek yang dibuat peserta didik adalah Menemukan kosa kata yang berkaitan dengan lingkungan sehat dengan tepat. Berikut ini adalah hasil belajar peserta didik pada siklus I yang bisa dilihat pada tabel berikut.

\begin{tabular}{|c|c|c|c|c|c|c|c|}
\hline \multirow{3}{*}{ Siklus I } & \multicolumn{4}{|c|}{ Pengetahuan } & \multicolumn{3}{|c|}{ Sikap } \\
\hline & \multicolumn{2}{|c|}{$\begin{array}{c}\text { Pesdik } \\
\text { tuntas }\end{array}$} & \multicolumn{2}{|c|}{$\begin{array}{l}\text { Pesdik belum } \\
\text { tuntas }\end{array}$} & $\begin{array}{c}\text { Pesdik } \\
\text { tuntas }\end{array}$ & \multicolumn{2}{|c|}{$\begin{array}{c}\text { Pesdik belum } \\
\text { tuntas }\end{array}$} \\
\hline & $\mathrm{Jml}$ & $\%$ & Jml & $\%$ & Jml \% & $\mathrm{Jml}$ & $\%$ \\
\hline Pertemuan 1 & 3 & 33 & 6 & 67 & 9100 & 0 & 0 \\
\hline
\end{tabular}

Tabel 1. Hasil Belajar Peserta Didik Siklus I

Berdasarkan Arikunto(2006: 250) bahwa tingkat penguasaan yang dicapai jika menggunakan prinsip belajar tuntas yaitu sekurang-kurangnya menguasai $\geq$ $75 \%$ atau jika $<75 \%$ maka tergolong belum tuntas. Dari hasil penilaian pengetahuan pada pembelajaran Tematik pada peserta didik kelas II sebanyak 9 siswa (33\%) telah mencapai KKM dan 6 siswa (67\%) tidak mencapai KKM. Berdasarkan data tersebut maka siswa kelas II belum mencapai ketuntasan belajar. Oleh karena itu perlu dilaksanakan pembelajaran pada siklus II.

Berikut ini adalah hasil belajar peserta didik pada siklus II yang bisa dilihat pada tabel berikut.

\begin{tabular}{ccccccccc}
\hline & \multicolumn{3}{c}{ Pengetahuan } & \multicolumn{3}{c}{ Sikap } \\
\cline { 2 - 9 } Siklus II & \multicolumn{2}{c}{$\begin{array}{c}\text { Pesdik } \\
\text { tuntas }\end{array}$} & $\begin{array}{c}\text { Pesdik belum } \\
\text { tuntas }\end{array}$ & \multicolumn{2}{c}{ Pesdik tunte } & $\begin{array}{c}\text { Pesdik belum } \\
\text { tuntas }\end{array}$ \\
\cline { 2 - 10 } & Jml & $\%$ & Jml & $\%$ & Jml & $\%$ & Jml & $\%$ \\
\hline Pertemuan 1 & 8 & 89 & 1 & 11 & 9 & 100 & 0 & 0
\end{tabular}

Tabel 2. Hasil Belajar Peserta Didik Siklus II

Pembelajaran berlangsung kondusif dan efektif juga menyenangkan. Banyak peserta didik yang termotiaktif. Jumlah peserta didik yang tuntas belajar mengalami peningkatan antara penilaian pengetahuan dan pengetahuan sikap yaitu sebanyak 8 peserta didik dari jumlah keseluruhan 9 peserta didik. Sesuai indikator yang telah ditetapkan, hasil belajar peserta didik meningkat signifikan. Dari 9 peserta didik yang dimintai komentarnya, seluruhnya mengatakan bahwa metode penggunaan alat peraga pawer point slid show dengan model pembelajaran project Based Learning dapat meningkatkan pemahaman materi. Dari hasil refleksi tersebut, Peneliti menyimpulkan bahwa tindakan perbaikan yang dilakukan telah berhasil.Perbaikan pembelajaran berakhir pada siklus kedua yaitu siklus I 33\% pada siklus 2 menjadi $89 \%$.

Dari dua siklus yang sudah dilaksanakan selama 2 pertemuan dapat dipastikan bahwa model pembelajaran $\mathrm{PjBL}$ dapat meningkatkan hasil belajar peserta didik pada

Tema hidup bersih dan sehat di rumah Kelas II di SD Negeri Gringgingsari Hal ini sesuai dengan konsep atau teori yang diungkap oleh Nanang Hanafiah dan Cucu Suhana (2009:30) bahwa langkah penerapan Model pembelajaran ini merupakan model pembelajaran inovatif yang melibatkan kerja proyek dimana peserta didik 
SHEs: Conference Series 3 (3) (2020) 1144- 1148

bekerja secara mandiri dalam mengkonstruksi pembelajarannya dan mengkulminasikannya dalam produk nyata. Memang benar adanya dengan model $\mathrm{PjBL}$ peserta didik akan membangun sendiri pengetahuannya dengan mengerjakan proyek yang diberikan. Peserta didik dapat memahami materi hidup bersih dan sehat di rumah dengan tepat. Pada siklus II peserta didik juga dapat memahami arti hidup bersih dan sehat di rumah dan menerapkan dalam kehidupan sehari-hari sehingga pengetahuan yang dihasilkan dapat tertanam dengan permanen. Hasil penelitian ini juga sesuai dengan penelitian sebelumnya yang dilakukan oleh Surya, dkk (2018) yang membuktikan bahwa model pembelajaran Project Based Learning (PjBL) dapat meningkatkan hasil belajar dan kreativitas peserta didik

\section{SIMPULAN}

Penerapan model pembelajaran Project Based Learning (PjBL)dapat meningkatkan hasil belajar peserta didik Kelas II pada materi Hidup bersih dan sehat di rumah. Peningkatan yang terjadi karena adanya kesan pembelajaran yang mendalam dari peserta didik tehadap materi yang diajarkan melalui setiap proyek yang dibuat. Peserta didik akan selalu teringat akan materi yang diajarkan dikarenakan mereka menemukan dan membangun sendiri pengetahuan mereka pada saat membuat proyek yang sudah disepakati. Berdasarkan penelitian yang telah dilaksanakan salah satu model pembelajaran yang harus dikuasai guru adalah PjBL karena model ini sangat cocok digunakan dalam keadaan pandemi seperti ini, apalagi dalam kondisi belajar dari rumah. Peserta didik akan membangun pengetahuannya sendiri dengan proyek yang sudah disepakati. Guru bisa memantau proses selama proyek dilaksanakan dengan bekerja sama dengan orang tua.

\section{DAFTAR PUSTAKA}

Mansur, 2007. Tujuan pendidikan dasar. Jakarta: Balai Pustaka (H.W. Fowlwer dalam Pandoyo,1997. Pendidikan Matematika: Balai Pustaka Bettencourt dalam Suparno, 1997. Pembelajaran Matematika: Balai Pustaka Suparno, 1997. Ketrampilan Tujuan Pengajaran: PT Gramedia Meier, 2002. Pengertian Belajar: Balai Pustaka Purwodarminto, 1988. Pengertian Kemampuan: Balai Pustaka

Mulyasa, 2002. Proses Pembelajaran Merupakan Interaksi Edukatif: Balai Pustaka Wardhani, 2004. Pembelajaran Aktif Kreatif Efektif dan Menyenangkan: PT Gramedia Hamalik, (2002:11). Metode Penyajian Bahan Dan Media Pendidikan: Balai Pustaka Wahyudi, dkk, 2009 :2.22, Pengertian Belajar: Balai Pustaka 